\title{
Inefficacy of \\ Methanol as a \\ Growth \\ Promoter in \\ Selected \\ Vegetable Crops
}

V. Esensee, D.I. Leskovar, and

A.K. Boales

Additional index words. cabbage, cantaloupe, cauliflower, onion, pepper, transplants, seedlings

Summary. Nonomura and Benson (1992) reported that foliar applications of dilute solutions of methanol caused growth and yield increases and reduced water use in several crops.

The request from commercial growers for explicit information regarding this report prompted our experiments using the same procedures. Growth of cantaloupe, pepper, cabbage, cauliflower and onion seedlings and mature plants were evaluated in the laboratory and greenhouse in 1993 and in the field in 1993 and 1994. Treatments of $0 \%, 10 \%, 20 \%, 30 \%$, or $40 \%$ methanol (v/v water) with $0.1 \%$ surfactant generally did not cause significant growth differences. Stem diameters or lengths, shoot fresh and dry weights, or root fresh and dry weights of seedlings were unaffected as a result of methanol treatment. In the field, cabbage head weight was slightly higher after methanol application only in 1993, whereas cantaloupe fruit weight and number were significantly lower in 1993, but not in 1994.

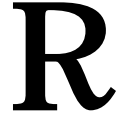

ecently, interest has focused on increased yields in several C3 crop species as a result of foliar applications of methanol solutions in an arid environment (Nonomura and Benson, 1992). Re-

Texas Agricultural Experiment Station, Texas AEM University, Uvalde, Texas 78801.

Texas Agricultural Experiment Station Journal series no. 31412. We thank Bart Wagner and David Bowers for their kind cooperation in the use of their fields and additionally to Speedling. The cost of publishing this paper was defrayed in part by the payment of page charges. Under postal regulations, this paper therefore must be hereby marked advertisement solely to indicate this fact. 
ported growth improvements of as much as $100 \%$ raised hopes of increased yields and farm incomes as a result of using these treatments, however, the data presented in that report lacked adequate statistical analysis.

The mode of action of methanol as a growth promoter is unknown, although it has been suggested that it may inhibit photorespiration (Nonomura and Benson, 1992). Methanol also may be assimilated in a sugar phosphate pathway in some C3 crop species as in Aspergillus niger (Maldonado et al., 1993). Methanol is a singlecarbon alcohol that is lipid-soluble and passively traverses bilipid membranes, effecting rapid incorporation into cells (Salisbury and Ross, 1992). Methanol is synthesized into serine and methionine and is oxidized to carbon dioxide in C3 plants; however, increased carbon dioxide fixation does not appear to be a major response to exogenously applied methanol (Cossins, 1964).

News articles in the popular press (Bishop, 1992), on a national radio program, and in at least one trade journal (Mauney, 1993) produced a demand from commercial growers for information regarding foliar applications of methanol solutions. The purpose of these studies was to determine whether foliar sprays of aqueous methanol enhanced plant growth and yields of various vegetables, and, if so, to determine what concentrations were optimal. Five vegetable species (cantaloupe, cauliflower, cabbage, onion, and pepper) were examined during three growth stages (seedling, transplant, and whole plant).

\section{Materials and methods}

'Explorer' cantaloupe (Cucumis melo L. var. veticulatus Naud. ), 'TAM Mild Jalapeño-1' pepper (Capsicum annuum L.), 'Blue Vantage' cabbage (Brassica oleracea L. var. capitata), 'Early Glacier' cauliflower (Brassica oleracea L. var. botrytis), and 'Texas Grano 438' onion (Allium cepa L.) were subjected to applications of methanol as seedlings, transplants, and mature plants in 1993. In 1994, 'Easy Rider' cantaloupe, 'Mitla' pepper, 'Blue Vantage' cabbage, 'Early Glacier' cauliflower, and 'Texas Grano 1015Y' onion were field-tested for growth responses to methanol treatment. Cantaloupe, pepper, and onion cultivars were different in the second year, because field trials were conducted in commercial stands using cultivars selected by the cooperating farmers. Care was taken to duplicate the conditions that were reported to be requisite to effect the desired plant responses, although tests on seedlings were not reported in the original work.

Emergency seedlings. Pepper, cabbage, cauliflower, and onion seeds were planted in Todd planter flats (model 100A), filled with moist tobacco peat-lite soilless medium (Speedling, Sun City, Fla.). These were covered with $1.25 \mathrm{ml}$ of vermiculite grade 2-3-4 (W.R. Grace \&Co., Cambridge, Mass. ), held at 77F (25C) and $98 \% \mathrm{RH}$ for 3 days, and then transferred to a greenhouse at 64/86F (18/ 30C) $(\mathrm{min} / \mathrm{max})$. Cantaloupes were sown in Todd planter flats (model 125 ) under the same conditions. A randomized complete-block design (RCBD) was used with four replicates. A flotation system was used to supply water and nutrients (Leskovar and Cantliffe, 1992). When all seedlings of any one species had at least one true leaf, (9 days after seeding [DAS] for cauliflower and cabbage, 14 DAS for peppers and onions, and 10 DAS for cantaloupe), 10 whole seedlings per treatment were removed, washed, blotted dry, weighed, oven-dried at $149 \mathrm{~F}$ (65C) for $72 \mathrm{~h}$, and weighed again. Subsequently, the remaining seedlings in the trays were sprayed in full sun to runoff with methanol formulations. Whole seedlings from each species were taken 1 week after the methanol applications, and comparisons were based on fresh and dry weights.

Transplants. Cabbage, cauliflower, onion, and pepper seeds were planted in Todd planter flats (model 100A, Seedling). Four replications per methanol formulation in a RCBD were used. Each cell was filled with moist tobacco peat-lite soilless medium. These were covered with 1.25 $\mathrm{ml}$ of vermiculite grade 2-3-4. Cantaloupe seeds were planted in Todd planter flats (model 125 ). Flats were placed into germination chambers at 77F (25C) and 98\% RH for 2 days, then into a greenhouse maintained at $64 / 86 \mathrm{~F} \quad(18 / 30 \mathrm{C}) \quad(\mathrm{min} / \max )$. Irrigation and fertilization (120 ppm $\mathrm{N}$, 53 ppm P, 100 ppm K) were by flotation as needed. Twenty-one DAS, seedlings were sampled to measure shoot diameter [0.4 inch $(1.0 \mathrm{~cm})$ above the crown, with a digital caliper], shoot length, leaf number, shoot and root fresh weight, and shoot and root dry weight. Leaf area was determined using a digital image system (DIAS, Decagon Devices, Pullman, Wash.). Root and shoot dry weights were determined and shoot : root ratios were calculated. The rest of the seedlings were treated with $0 \%, 10 \%, 20 \%, 30 \%$, or $40 \%$ methanol/water $(\mathrm{v} / \mathrm{v})$. At 28 DAS, the same measurements made on nontreated seedlings were performed on treated seedlings.

Field experiments. Six-week-old transplants of each species remaining from the previous experiment were transplanted to a sandy clay loam soil (Uvalde-Knippa-Montell association) at the Texas Agricultural Experiment Station, Uvalde, on 9 Mar. 1993. The original treatments and replications were maintained. Soil analyses indicated that no preplant fertilization was required. Transplants were planted on 8-inch-high beds with 3 -ft centers. Plants were grown one row per bed, 1 $\mathrm{ft}$ between plants in plots $15 \mathrm{ft}$ long. Water and fertilizer were supplied by a T-tape drip-irrigation system, twelve inches between emitters. Methanol solutions were applied at 74, 88, and 109 DAS in full sun, at noon, using a $\mathrm{CO}_{2}$ backpack sprayer (Weed Systems Equipment, Keystone Heights, Fla.). Once-over harvests were performed on all crops, except cantaloupe, which was harvested three times. Cauliflower was harvested 122 DAS, cabbage 136 DAS, peppers 154 DAS, and onions 155 DAS. Cantaloupes were harvested at 151, 158, and 165 DAS. A standard size classification by number of fruit per box was used, with five mutually exclusive fruit diameter classes: N23 ( $41 / 8$ in.), N18 (>4 1/8 in. to $45 / 8$ in.), N15 (>45/8in. to $53 / 8 \mathrm{in}.), \mathrm{N} 12$ (>5 $3 / 8$ in. to $5 \frac{3}{4}$ in.), and N9 (>5 $3 / 4$ in. ). Yield data from the three harvest dates were pooled and analyzed. Data analysis was performed using the SAS general linear models procedure (SAS Institute, Cary, N.C.).

In Spring 1994, using the same experimental design, 6-week-old cabbage and cauliflower seedlings were planted at the same location as in 1993. Twelve-week-old onion transplants were integrated into a commercial onion field near Crystal City, Texas, in February, while cantaloupe and pepper plots were part of commercial plantings near Batesville, Texas, which were planted in late March. The procedures of the previous year were followed, 2.0 
Table 1. The effects of application of methanol $(\mathrm{MeOH})$ solutions on cantaloupe

\begin{tabular}{lcc}
\hline Treatment & $\begin{array}{c}\text { Root fresh } \\
\text { wt (mg) }\end{array}$ & $\begin{array}{c}\text { Root dry } \\
\text { wt (mg) }\end{array}$ \\
\hline $0 \% \mathrm{MeOH}$ & 141.7 & 9.0 \\
$10 \% \mathrm{MeOH}$ & 157.5 & 9.4 \\
$20 \% \mathrm{MeOH}$ & 158.3 & 9.5 \\
$30 \% \mathrm{MeOH}$ & 162.5 & 9.0 \\
$40 \% \mathrm{MeOH}$ & 177.5 & 10.4 \\
Contrast & & \\
$\quad$ Linear & $\mathrm{NS}$ & $\mathrm{NS}$ \\
$\quad$ Quadratic & $\dagger$ & $\mathrm{NS}$ \\
Cubic & $\dagger$ & $\mathrm{NS}$ \\
\hline
\end{tabular}

${ }^{+}$Significant at $P$ 0.10, respectively.

ft between plots, guard beds on each side, but with 20-ft-long plots and an additional two replicates per treatment. Onions, peppers, and cantaloupe were planted in two-row beds.

\section{Results}

Shoot and root fresh and dry weights of emergent seedlings of onion, cabbage, cauliflower, and pepper were not affected by methanol (data seedling root fresb and dry weights.

not shown), however, cantaloupe weights were. Cantaloupe seedlings benefited from $40 \%$ methanol treatment, as seen in root fresh weight, but not root dry matter accumulation (Table 1). Transplants treated with methanol exhibited no differences in growth in the greenhouse (shoot diameter, shoot length, leaf number, shoot and root fresh weights, shoot and root dry weights, leaf area, and root: shoot ratio) regardless of species or treatment (data not shown).

In the field, none of the treatments applied to jalapeño-type peppers resulted in yield increases during either of the two seasons (data not shown ). Average individual pepper fruit weights of 'TAM Mild Jalapeno- 1' ranged from 13.2 to 14.4 grams in 1993 and from 8.2 to 8.6 grams in 'Mitla' in 1994. The control produced the highest average total yield of peppers in both years $(7.94 \mathrm{lb}$ in 1993 and $5.73 \mathrm{lb}$ 1994) with $40 \%$ methanol (7.05 lb in 1993) and the least in each year (5.51 lb in 1994) with $30 \%$ methanol. This trend indicates that metha-

Table 2. Cabbage and cauliflower head weights, and cauliflower shoot fresb weight as affected by methanol $(\mathrm{MeOH})$ foliar sprays in 1993.

\begin{tabular}{lcccc}
\hline & Cabbage & \multicolumn{2}{c}{ Cauliflower } \\
\cline { 2 - 3 } Treatment & Head wt (lb) & & Head wt (lb) & Shoot wt (lb) \\
\hline Control & 1.06 & 0.68 & 3.06 \\
$10 \% \mathrm{MeOH}$ & 1.43 & 0.46 & 2.80 \\
$20 \% \mathrm{MeOH}$ & 1.41 & 0.66 & 3.09 \\
$30 \% \mathrm{MeOH}$ & 1.34 & 0.33 & 2.23 \\
$40 \% \mathrm{MeOH}$ & 1.43 & 0.33 & 2.49 \\
Contrast & & & NS \\
$\quad$ Linear & $\dagger$ & NS & NS \\
Quadratic & NS & NS & NS \\
Cubic & NS & NS & \\
\hline
\end{tabular}

$\overline{\text { Ns, }}+$ Significant at $\mathrm{P} \leq 0.10$, respectipely.

Table 3, Cantaloupe responses to foliar application of methanol (MeOH) solutions as expressed by total number, total weight and size classes of 15 (N15) and 18 (N18) fruit per standard box in 1993.

\begin{tabular}{|c|c|c|c|c|c|c|}
\hline \multirow[b]{2}{*}{ Treatment } & \multicolumn{2}{|c|}{ N15 } & \multicolumn{2}{|c|}{ N18 } & \multirow{2}{*}{$\begin{array}{c}\text { Total }^{x} \\
\text { No. } \\
\end{array}$} & \multirow{2}{*}{$\begin{array}{r}\text { Total } \\
\text { Wt (lb) }\end{array}$} \\
\hline & No. & $\mathrm{Wt}(\mathrm{lb})$ & No. & Wt (lb) & & \\
\hline Control & 15 & 26.4 & 5 & 8.5 & 28.8 & 60.2 \\
\hline $10 \% \mathrm{MeOH}$ & 8.3 & 18.4 & 5 & 8.7 & 22.0 & 48.5 \\
\hline $20 \% \mathrm{MeOH}$ & 9.3 & 20.8 & 6.3 & 10.2 & 22.0 & 48.9 \\
\hline $30 \% \mathrm{MeOH}$ & 8 & 17.8 & 4.3 & 7.1 & 21.0 & 47.6 \\
\hline $40 \% \mathrm{MeOH}$ & 9.5 & 20.9 & 2.3 & 3.6 & 20.8 & 47.4 \\
\hline \multicolumn{7}{|l|}{ Contrast } \\
\hline Linear & ** & $\dagger$ & NS & NS & ** & $\dagger$ \\
\hline Quadratic & NS & NS & $\dagger$ & $\dagger$ & NS & NS \\
\hline Cubic & NS & NS & NS & NS & NS & NS \\
\hline
\end{tabular}

Total number and total weight include N9, N12, N15, N18, and N23 numbers and weights.

${ }^{+}$Significant at $P<0.10$, respectively. nol has a deleterious effect on peppers.

Onion bulb yield was similar to that of pepper, with the control plants outperforming those treated with methanol in both years (data not shown). Average bulb weights ranged from 0.62 to $0.71 \mathrm{lb}$ in 1993 and from 0.24 to $0.33 \mathrm{lb}$ in 1994 .

Field treatment of cabbage resulted in head diameters from 3.74 to 4.21 inches in 1993 and 3.46 to 3.62 inches in 1994, although treatments were nonsignificant (data not shown). Mean head weights of the control plants were lower than those of the $10 \%$, $20 \%$, and $40 \%$ methanol treatments in 1993 (Table 2).

In 1993, cauliflower shoot biomass totals (expressed as head plus shoot weight ) were nonsignificant (Table 2 ). Results-in 1994 showed no significant differences among treatments.

In cantaloupe, there were more control fruit than methanol-treated fruit in 1993 (Table 3). Differences among treatments in fruit weight were nonsignificant; however, the number of medium-sized fruit (N15) produced in the control was greater than that of the number harvested from the methanol-treated plants. In 1994, the results in cantaloupe were similar and nonsignificant (data not shown).

\section{Discussion}

In most instances, the methanoltreated plants performed the same or worse than the controls. Methanol solution effects on seedlings were no different from the effects of the control. Nonomura and Benson (1992) indicated that phytotoxicity should be anticipated, but in our studies most plant growth processes appeared not have been impaired by methanol.

Finally, the enhanced fresh weight promotion in cantaloupe seedlings did not result in improved fruit production in the field. The consistent lack of a promotive response in cauliflower, cantaloupes, onion, and pepper due to methanol, and negligible improvements in cantaloupe seedlings and cabbage head weight, raises questions on the efficacy of methanol treatment of these crop species. In light of recent corroboration of our findings in other crops after our 2 years of field study (Barnes and Houghton, 1994; Dami, et al., 1994; Funderburg, et al., 1994; Hartz, et al., 1994; McGiffen, et al., 1994; Nelson, et al., 1994), methanol treatment is not recommended. 


\section{Literature Cited}

Barnes, C.E. and W.E. Houghton. 1994. Effect of methanol applications on Acala cotton in New Mexico. In: D.J. Herber and D.A. Richter (eds.). 1994 Proc. Beltwide Cotton Conf. Natl. Cotton Council, San Diego.

Bishop, J.E. 1992. A better rose: Spray methanol in intense sun. The Wall Street Journal, 14 Oct.

Cossins, E.A. 1964. The utilization of carbon-l compounds by plants. I. The metabolism of methanol- $\mathrm{C}^{14}$ and it's role in amino acid biosynthesis. Can. J. Biochem. 42:1793-1802.

Dami, I., C. Stushnoff and R. Hamman. 1994. Physiological and biochemical responses of grapevines to methanol. HortScience 29:441. (Abstr.)
Funderburg, E.R., R.L. Hutchinson, and T.A. Burch. 1994. Effect of foliar applications of methanol, urea andiron on cotton yield in Louisiana. In: D.J. Herber and D.A. Richter (eds.). 1994 Proc. Beltwide Cotton Conf. Natl. Cotton Council, San Diego.

Hartz, T. K., K.S. Mayberry, M.E. McGiffen, M. LeStrange, G. Miyao, and A. Baameur. 1994. Foliar methanol application ineffective in tomato and melon production. HortScience 29:1087.

Leskovar, D.I. and D.J. Cantliffe. 1992. Pepper seedling growth response to drought stress and exogenous abscisic acid. J. Amer. Soc. Hort. Sci. 117:389-393.

Maldonado, N. C., A.M. Stasser de Saad, and D.A.S. Callieri. 1993. Methanol utilization by a strain of Aspergillus niger: Influence on the synthesis and activity of pectinases. World J. Microbiol. Biotechnol. 9:202-204.
Mauney, J. 1993. Is wood alcohol in the future of cotton production? Cotton Grower 29(1):36A

McGiffen, Jr., M. E., J. Manthey, A. Baameur, R.L. Greene, B.A. Faber, J.A. Downer, and J. Aguiar. 1994. Field tests of methanol as a crop yield enhancer. HortScience 29:459. (Abstr.)

Nelson, J. M., F.S. Nakayama, H.M. Flint, R.L. Garcia, and G.L. Hart. 1994. Methanol treatments on Pima and upland cotton. In: D.J. Herber and D.A. Richter (eds.). 1994 Proc. Beltwide Cotton Conf. Natl. Cotton Council, San Diego.

Nonomura, A.M. and A.A. Benson. 1992. The path of carbon in photosynthesis: Improved crop yields with methanol. Proc. Natl. Acad. Sci. USA 89:9794-9798.

Salisbury, F.B. and C. W. Ross. 1992. Plant physiology. Wadsworth, Belmont, Calif. 